\title{
Synthesis and Photophysical Studies of a Pyrenylindole and a Phenalenoindole Obtained from Dehydroamino Acid Derivatives - Application as Fluorescent Probes for Biological Systems
}

\author{
Goreti Pereira, ${ }^{[a]}$ Ana S. Abreu, ${ }^{[a, b]}$ Elisabete M. S. Castanheira, ${ }^{*[b]}$ Paulo J. G. Coutinho, ${ }^{[b]}$ \\ Paula M. T. Ferreira, ${ }^{*[a]}$ and Maria-João R. P. Queiroz ${ }^{[a]}$
}

Keywords: Cyclization / Palladium / Peptides / Fluorescent probes / Nitrogen heterocycles / Membranes

Two pyrenyl-dehydroamino acid derivatives were cyclized by a metal-assisted $\mathrm{C}-\mathrm{N}$ intramolecular cyclization developed in our research group, to give a pyrenylindole and a phenalenoindole. The pyrenylindole was inserted into a peptide by solid-phase coupling, with use of a 2-chlorotrityl chloride resin and a Fmoc strategy. The photophysical properties of the pyrenylindole and phenalenoindole in several solvents were studied and showed that these compounds can be used as fluorescence probes. The results obtained with the peptide labelled with the pyrenylindole moiety show potential for use of this compound as a fluorescence label avoiding the aggre- gation propensity of pyrene compounds. Photophysical studies of the pyrenylindole and of the phenalenoindole in lipid membranes were also carried out. Steady-state fluorescence anisotropy measurements revealed that both compounds adopt locations inside the lipid bilayers and are able to report the transition between the gel and liquid-crystalline phases. The results point to potential use of these compounds as fluorescent probes for biological systems.

( Wiley-VCH Verlag GmbH \& Co. KGaA, 69451 Weinheim, Germany, 2009)

\section{Introduction}

Because of their special photophysical behaviour namely, high fluorescence quantum yields, long excitedstate lifetimes and the ability to form excimers - pyrene and its derivatives have been widely used as versatile fluorescence probes in various complex systems such as polymers and micelles. ${ }^{[1]}$ When inserted into peptide chains, pyrene compounds have also been used in conformational studies. Pyrenylalanine is one of the fluorescent probes used in peptides and proteins and there are several reports describing the synthesis and applications of this amino acid. ${ }^{[2]}$ For further extension of pyrene systems, heterocyclic pyrene analogues containing thiophene, pyridine and pyrrole have been prepared. ${ }^{[3]}$ Recently, Fang et al. described the synthesis and photophysical properties of a series of pyrene[2,1-b]pyrroles. ${ }^{[3 \mathrm{~d}]}$ These compounds were prepared by Hemetsberger-Knittel reactions, involving Knoevenagel condensation of a pyrene-1-aldehyde and methyl azidoacetate in the presence of sodium methoxide. Some of the compounds ob-

[a] Centro de Química (CQ-UM), Universidade do Minho, Campus de Gualtar, 4710-057 Braga, Portugal

Fax: +351-253604382

E-mail: pmf@quimica.uminho.pt

[b] Centro de Física (CFUM), Universidade do Minho,

Campus de Gualtar, 4710-057 Braga, Portugal

Fax: +351-253604061

E-mail: ecoutinho@fisica.uminho.pt

Supporting information for this article is available on the WWW under http://dx.doi.org/10.1002/ejoc.200900351. tained were then used as selective and sensitive sensors for fluoride ion and guanine. ${ }^{[4,5]}$

Recently we have described the syntheses of several pyrenyldehydroamino acid derivatives by Suzuki-Miyaura coupling reactions between $\beta$-bromodehydroaminobutyric acid or $\beta$-bromodehydrophenylalanine derivatives and pyrene-1boronic acid. The photophysical properties and electrochemical behaviour of some of these compounds were also studied. ${ }^{[6]}$ In continuation of this work and in order to obtain highly fluorescent molecules in different environments, it was decided to use two of the prepared compounds as substrates in a metal-assisted $\mathrm{C}-\mathrm{N}$ cyclization reaction developed in our research group. ${ }^{[7]}$ The $Z$ isomers of the methyl esters of $N$-tert-butoxycarbonyl- $\beta$-(pyren-1-yl)dehydroaminobutyric acid and of $N$-tert-butoxycarbonyl- $\beta$ (pyren-1-yl)dehydrophenylalanine were thus treated with palladium acetate and copper acetate in DMF at $160{ }^{\circ} \mathrm{C}$ to give a phenalenoindole and a 3-pyrenylindole, respectively. The photophysical properties of these compounds, as well as those of a peptide conjugate with the pyrenylindole moiety, were studied in several solvents. The interactions of the two compounds with lipid membranes were also evaluated.

\section{Results and Discussion}

The (Z)- $\beta$-bromodehydrophenylalanine derivative $(Z)-1$ and the (Z)- $\beta$-bromodehydroaminobutyric acid derivative $(Z)-2$ were treated with (pyren-1-yl)boronic acid under Su- 


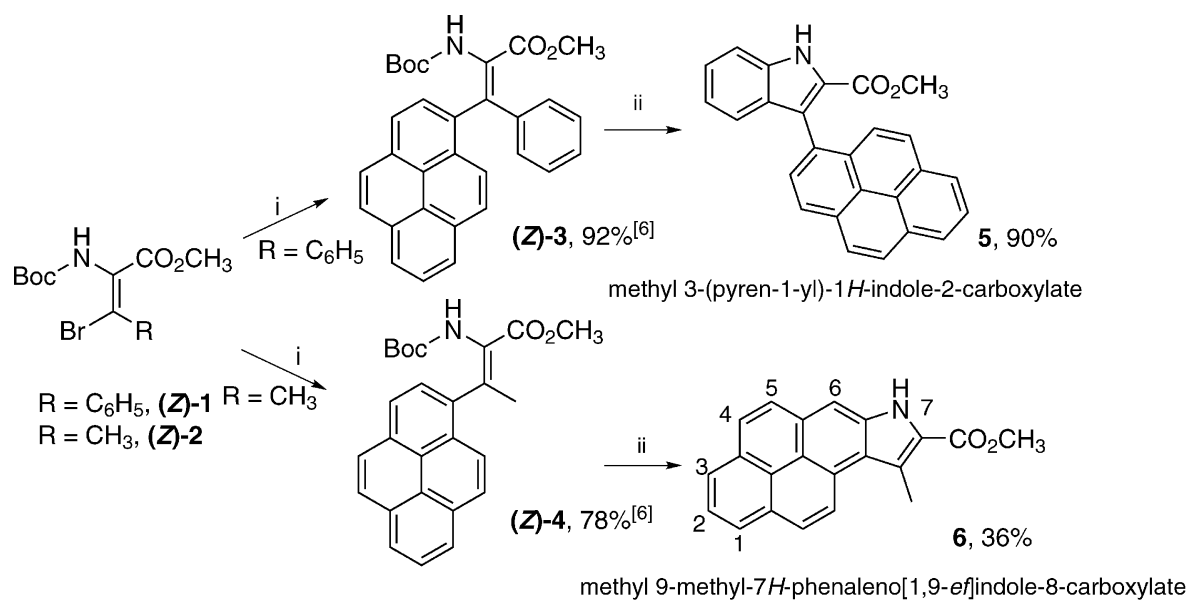

i) pyren-1-yl boronic acid (1.5 equiv.), $\mathrm{Cs}_{2} \mathrm{CO}_{3}$ (1.4 equiv.), $\mathrm{PdCl}_{2}$ (dppf): $\mathrm{CH}_{2} \mathrm{Cl}_{2}$ (1:1) (10 mol-\%), THF/ $\mathrm{H}_{2} \mathrm{O}(1: 1), 90 \stackrel{\circ}{ } \mathrm{C}$ ii) $\mathrm{Pd}(\mathrm{OAc})_{2}(50 \mathrm{~mol}-\%), \mathrm{Cu}(\mathrm{OAc})_{2}$ (3 equiv.), DMF, $160^{\circ} \mathrm{C}, 3-4 \mathrm{~h}$, under $\mathrm{Ar}$.

Scheme 1. Synthesis of a pyrenylindole and a phenalenoindole.

zuki cross-coupling conditions to give the (Z)- $\beta$-pyrenyldehydrophenylalanine derivative ( $Z$ )-3 and the (Z)- $\beta$-pyrenyldehydroaminobutyric acid derivative $(Z)-4 .{ }^{[6]}$ Compounds $(Z)-\mathbf{3}$ and ( $Z$ )-4 were used as substrates in an intramolecular metal-assisted $\mathrm{C}-\mathrm{N}$ cyclization developed in our group ${ }^{[7]}$ affording the pyrenylindole 5 and the phenalenoindole 6 (Scheme 1).

The mechanism proposed by us ${ }^{[8]}$ for the cyclization reaction involves electrophilic attack of $\mathrm{Pd}(\mathrm{OAc})_{2}$ on the aromatic ring and on the nitrogen, followed by extrusion of $\mathrm{Pd}^{0}$. The $\mathrm{Pd}^{0}$ is reoxidized to $\mathrm{Pd}^{\mathrm{II}}$ by $\mathrm{Cu}(\mathrm{OAc})_{2}$, to avoid the need for use of a stoichiometric amount of $\mathrm{Pd}(\mathrm{OAc})_{2}$. As acetic acid is formed, the Boc group is removed. Methyl 3-(pyren-1-yl)-1 $H$-indole-2-carboxylate (5) was obtained in a high yield as the product of isomerization followed by cyclization and loss of the Boc group. This kind of isomerization followed by cyclization to the indole derivative had already been observed by us in the intramolecular cyclization of a ( $Z$ )- $\beta$-(benzo[b]thienyl)dehydrophenylalanine derivative. ${ }^{[8]}$ On the other hand, methyl 9-methyl-7H-phenaleno[1,9-ef]indole-8-carboxylate (6) was obtained only in moderate yield as a result of direct cyclization with loss of the Boc group. In this reaction an $18 \%$ yield of the starting material ( $Z$ )-4 was also isolated.

The ${ }^{1} \mathrm{H}$ NMR spectra of compounds 5 and $\mathbf{6}$ in $\mathrm{CDCl}_{3}$ each show a broad singlet for NH at 9.32 and $9.185 \mathrm{ppm}$, respectively. The ${ }^{1} \mathrm{H}$ NMR spectrum of compound 5 shows two triplets at $\delta=7.11$ and $7.42 \mathrm{ppm}$ and two doublets at $\delta=7.31$ and $7.57 \mathrm{ppm}$ for the indole nucleus, which were confirmed by HMQC and HMBC. The rest of the aromatic protons give signals between 7.90 and $8.16 \mathrm{ppm}$. The ${ }^{1} \mathrm{H}$ NMR of compound $\mathbf{6}$ shows a multiplet between 7.93 and $8.00 \mathrm{ppm}$ that integrates for three protons, a singlet at $\delta=$ $8.08 \mathrm{ppm}$ due to $6-\mathrm{H}$ and four doublets each corresponding to one proton at $8.12,8.23,8.28$ and $8.97 \mathrm{ppm}$.

Compound 5 was inserted into a peptide after basic hydrolysis of the methyl ester. Treatment of compound $\mathbf{5}$ with a solution of sodium hydroxide thus afforded the carboxylic acid 7 in $83 \%$ yield, and this was then coupled to a tetrapeptide synthesized by standard solid-phase peptide synthesis (SPPS) (Scheme 2). $N$-Fluorenylmethoxycarbonylglycine ( $N$-Fmoc-Gly-OH) was loaded onto a 2-chlorotrityl chloride resin and the loading amount was determined to be $0.33 \mathrm{molg}^{-1}$. The peptide was elongated by a $\mathrm{N}^{\alpha}-\mathrm{Fmoc}$ strategy, and couplings were carried out with diisopropylcarbodiimide (DIC) and 1-hydroxybenzotriazole (HOBt). Compound 7 was coupled under solid-phase conditions by the same methodology. The peptide was cleaved from the resin with a mixture of 2,2,2-trifluoroethanol (TFE) and acetic acid ( $\mathrm{AcOH})$ in dichloromethane to give the peptide 8 in $49 \%$ yield.

The absorption and fluorescence properties of the pyrenylindole 5 and of the phenalenoindole 6 were studied in several solvents. The maximum absorption $\left(\lambda_{\mathrm{abs}}\right)$ and emission wavelengths $\left(\lambda_{\mathrm{em}}\right)$, molar extinction coefficients $(\varepsilon)$ and fluorescence quantum yields $\left(\Phi_{\mathrm{F}}\right)$ of the two indoles are presented in Table 1 . The normalized fluorescence spectra of compounds $\mathbf{5}$ and $\mathbf{6}$ in all solvents studied are shown in Figures 1 and 2 (for compound 5) and in Figures 3 and 4 (for compound 6). Examples of absorption spectra are displayed as insets.

Each compound presents a high $\varepsilon$ value $(\varepsilon>$ $2.3 \times 10^{4} \mathrm{M}^{-1} \mathrm{~cm}^{-1}$ ) at the lowest energy maximum in all solvents studied (Table 1). The near-ultraviolet absorption of indole and its derivatives has been attributed to two strongly overlapping $\pi \rightarrow \pi^{*}$ transitions, ${ }^{[9-11]}$ with an average $\varepsilon$ value for unsubstituted indole of $5550 \mathrm{M}^{-1} \mathrm{~cm}^{-1}$, which also explains its relatively high fluorescence quantum yield. ${ }^{[12]} \mathrm{A}$ carboxylate group is also present in each indolic compound, and it is known that many carbonyl compounds exhibit low fluorescence quantum yields due to the lowlying $n \rightarrow \pi^{*}$ state. In these compounds, the $\pi \rightarrow \pi^{*}$ and $n \rightarrow \pi^{*}$ electronic transitions can be close in energy, resulting in state-mixing. ${ }^{[13]}$ The high values of the molar extinction coefficients for compounds $\mathbf{5}$ and $\mathbf{6}$ can be explained by a predominance of $\pi \rightarrow \pi^{*}$ character (Table 1). 


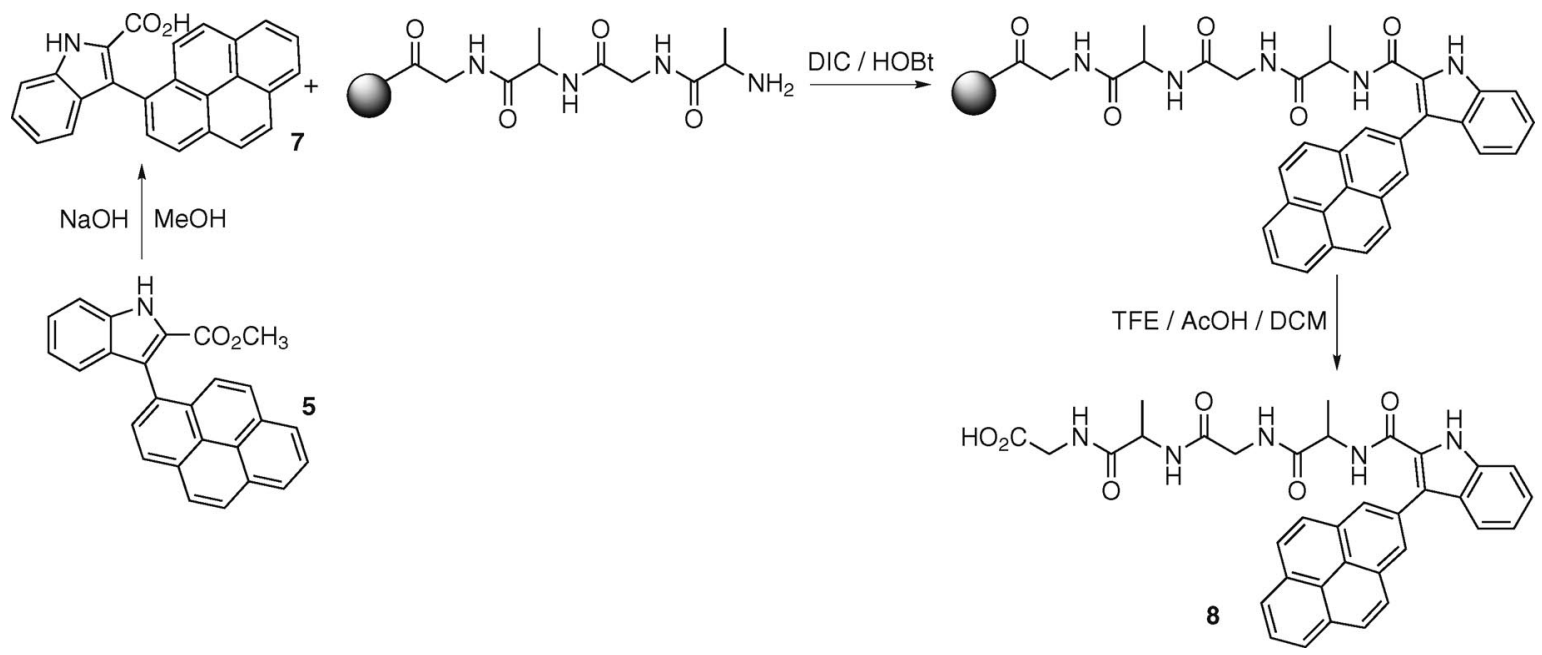

Scheme 2. Synthesis of a peptide labelled with pyrenylindole by solid-phase peptide synthesis.

Table 1. Maximum absorption $\left(\lambda_{\text {abs }}\right)$ and emission wavelengths $\left(\lambda_{\mathrm{em}}\right)$, molar extinction coefficients $(\varepsilon)$ and fluorescence quantum yields $\left(\Phi_{\mathrm{F}}\right)$ for the pyrenylindole 5 and the phenalenoindole $\mathbf{6}$.

\begin{tabular}{|c|c|c|c|c|c|c|}
\hline Solvent & $\begin{array}{l}\lambda_{\text {abs }}[\mathrm{nm}]\left(\varepsilon\left[10^{4} \mathrm{M}^{-1} \mathrm{~cm}^{-1}\right]\right) \\
\mathbf{5}\end{array}$ & 6 & $\begin{array}{l}\lambda_{\mathrm{em}}[\mathrm{nm}] \\
\mathbf{5}\end{array}$ & 6 & $\begin{array}{l}\Phi_{\mathrm{F}} \\
\mathbf{5}^{[\mathrm{a}]}\end{array}$ & $6^{[\mathrm{b}]}$ \\
\hline Cyclohexane & $\begin{array}{l}344(3.32), 296(2.19) \\
277(4.58), 241(7.63)\end{array}$ & $\begin{array}{l}403(2.30), 381(1.71), 300(1.53) \\
288(1.53), 250(1.77)\end{array}$ & 412 & $405,430,456$ & 0.73 & 0.54 \\
\hline Dioxane & $\begin{array}{l}345(4.69), 300(3.22) \\
278(6.23), 242(10.60)\end{array}$ & $\begin{array}{l}408(4.11), 386(3.31), 302(3.06), \\
290(3.11), 252(3.54)\end{array}$ & 419 & $411,437,465$ & 0.76 & 0.61 \\
\hline Diethyl ether & $\begin{array}{l}343(3.01), 299(2.00), \\
277(3.82), 241(6.90)\end{array}$ & $\begin{array}{l}405(3.19), 383(2.56), 300(2.43) \\
288(2.48), 251(2.69)\end{array}$ & 420 & $409,436,465$ & 0.68 & 0.71 \\
\hline Chloroform & $\begin{array}{l}346(2.87), 300(2.13), \\
280(3.97)\end{array}$ & $\begin{array}{l}408(3.38), 386(2.73), 303(2.66) \\
291(2.71)\end{array}$ & 439 & $414,441,468$ & 0.65 & 0.56 \\
\hline Ethyl acetate & $\begin{array}{l}344(3.68), 299(2.60), \\
277(4.74)\end{array}$ & $\begin{array}{l}405(3.33), 383(2.70), 300(2.72) \\
287(2.90)\end{array}$ & 422 & $410,438,465$ & 0.78 & 0.81 \\
\hline Dichloromethane & $\begin{array}{l}345(2.54), 300(1.85) \\
279(3.45), 243(5.98)\end{array}$ & $\begin{array}{l}406(3.42), 385(2.71), 302(2.49) \\
290(2.52), 252(2.91)\end{array}$ & 433 & $411,435,462$ & 0.65 & 0.51 \\
\hline Dimethylformamide & $346(2.81), 302(2.09)$ & $\begin{array}{l}410(3.17), 388(2.59), 303(2.52), \\
290(2.58)\end{array}$ & 431 & $416,440,469$ & 0.80 & 0.80 \\
\hline Acetonitrile & $\begin{array}{l}344(4.60), 299(3.21) \\
277(5.98), 241(11.11)\end{array}$ & $\begin{array}{l}404(3.43), 383(2.78), 300(2.76) \\
288(2.81), 251(3.26)\end{array}$ & 432 & $410,434,461$ & 0.58 & 0.51 \\
\hline Dimethyl sulfoxide & $348(4.02), 303(3.04)$ & $\begin{array}{l}413(3.98), 391(3.35), 304(3.25) \\
292(3.24)\end{array}$ & 433 & $419,444,475$ & 0.83 & 0.78 \\
\hline Ethanol & $\begin{array}{l}343(2.60), 302(1.88), \\
277(3.32), 241(6.52)\end{array}$ & $\begin{array}{l}407(2.87), 386(2.48), 301(2.45) \\
289(2.53), 251(2.84)\end{array}$ & 445 & $414,438,464$ & 0.55 & 0.66 \\
\hline Methanol & $\begin{array}{l}343(4.15), 301(3.01) \\
276(5.25), 240(10.07)\end{array}$ & $\begin{array}{l}406(3.31), 384(2.82), 300(2.80), \\
289(2.91), 251(3.34)\end{array}$ & 458 & $414,438,466$ & 0.38 & 0.59 \\
\hline
\end{tabular}

[a] Relative to anthracene in ethanol $\left(\Phi_{\mathrm{F}}=0.27\right.$ at $\left.25^{\circ} \mathrm{C}\right) \cdot{ }^{[18]}$ Error about $10 \%$. [b] Relative to 9,10 -diphenylanthracene in ethanol $\left(\Phi_{\mathrm{F}}\right.$ $=0.95$ at $\left.25^{\circ} \mathrm{C}\right) .{ }^{[19]}$ Error about $10 \%$. Solvent cut-offs: chloroform: $250 \mathrm{~nm}$; ethyl acetate: $265 \mathrm{~nm}$; dimethyl sulfoxide: $270 \mathrm{~nm}$; $N, N$ dimethylformamide: $275 \mathrm{~nm}$.

The pyrenylindole 5 presents an absorption spectrum similar to that of the parent compound $(Z)-3$, previously studied by us, ${ }^{[6]}$ in which the pyrene ring is conjugated with the $\alpha, \beta$-double bond of the dehydroamino acid and the phenyl ring. A completely non-structured fluorescence emission is observed in all solvents studied (Figures 1 and 2). In polar solvents, an appreciable bathochromic shift can be detected, together with a band enlargement. This behaviour points to a strong intramolecular charge transfer (ICT) character of the excited state. Strong excited state CT has also been reported for pyrene-dimethylaniline derivatives. ${ }^{[14,15]} \mathrm{CT}$ character in nonpolar solvents at room tem- perature was also observed for 1-phenylpyrene derivatives substituted with methyl carboxylate groups, ${ }^{[16]}$ as observed here for compound 5. Intramolecular exciplex formation between pyrene and $N$-substituted indole moieties connected through propyl chains has also been described by other authors. ${ }^{[17]}$

The phenalenoindole 6 exhibits absorption and emission spectra roughly similar in shape to those of the parent compound $(Z)-4,{ }^{[6]}$ in which the dehydroamino acid double bond is conjugated with the pyrene $\pi$-system electrons. A more pronounced vibrational structure can be detected in the absorption spectra of compound 6 (Figures 3 and 4), 


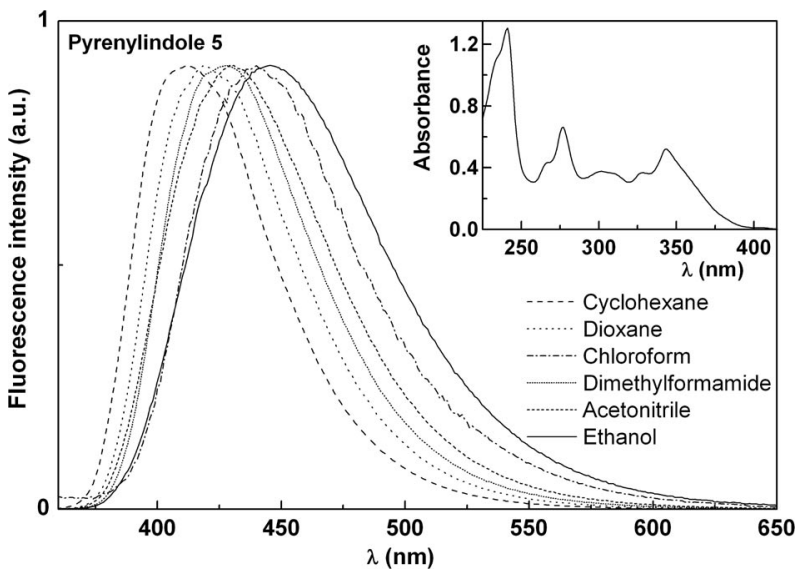

Figure 1. Normalized fluorescence spectra of solutions $\left(3 \times 10^{-6} \mathrm{M}\right)$ of the pyrenylindole $\mathbf{5}$ in several solvents (cyclohexane, dioxane, chloroform, dimethylformamide, acetonitrile and ethanol; $\lambda_{\mathrm{exc}}=$ $345 \mathrm{~nm})$. Inset: absorption spectrum of a solution $\left(2 \times 10^{-5} \mathrm{M}\right)$ of 5 in ethanol, as an example.

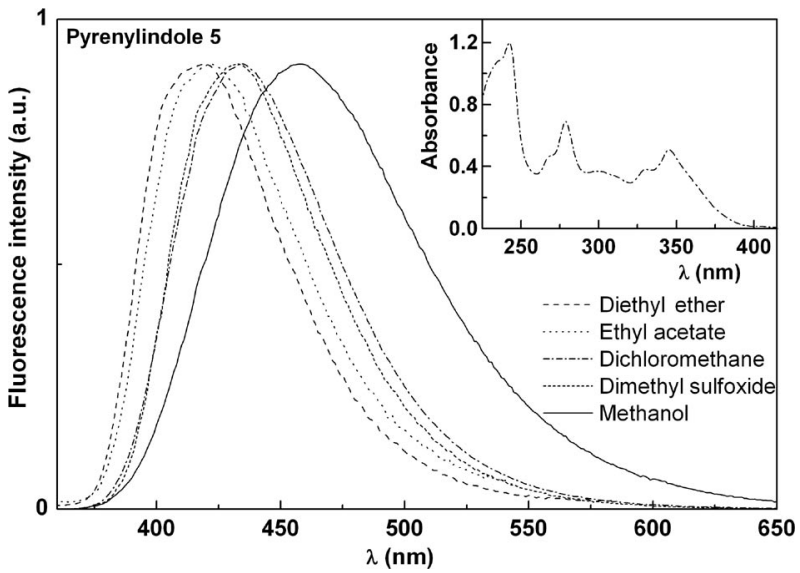

Figure 2. Normalized fluorescence spectra of solutions $\left(3 \times 10^{-6} \mathrm{M}\right)$ of the pyrenylindole $\mathbf{5}$ in several solvents (diethyl ether, ethyl acetate, dichloromethane, dimethylsulfoxide, and methanol; $\lambda_{\mathrm{exc}}=$ $345 \mathrm{~nm})$. Inset: absorption spectrum of a solution $\left(2 \times 10^{-5} \mathrm{M}\right)$ of 5 in dichloromethane.

together with a $10 \mathrm{~nm}$ red shift in emission relative to the parent compound in cyclohexane. ${ }^{[6]}$ Absorption and fluorescence spectra are similar to those reported for similar pyreno[2,1-b]pyrroles, ${ }^{[3 \mathrm{~d}]}$ as are the absorption and emission maximum values. In polar solvents compound $\mathbf{6}$ displays a small bathochromic shift in emission, together with an increase in the intensity ratio between the second and the first main peaks (Figures 3 and 4 and Table 1). These results show that, for this compound, a small CT character of the excited state is to be expected.

Solvatochromic shifts caused by general (not specific) solvent effects are often described by the Lippert-Mataga equation [Equation (1)], which relates the energy difference between absorption and emission maxima to the orientation polarizability. ${ }^{[20,21]}$

$\bar{v}_{\text {abs }}-\bar{v}_{\mathrm{fl}}=\frac{1}{4 \pi \varepsilon} \frac{2 \Delta \mu^{2}}{h c R^{3}} \Delta f+$ const

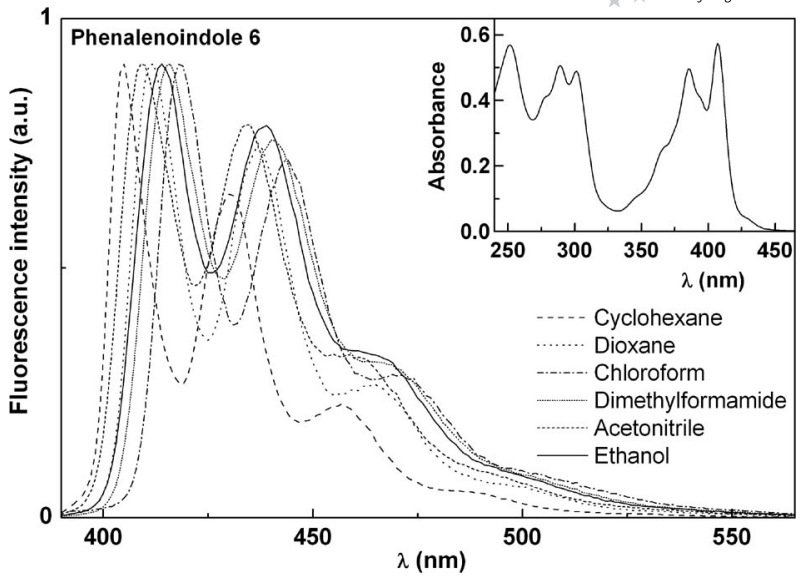

Figure 3. Normalized fluorescence spectra of solutions $\left(3 \times 10^{-6} \mathrm{M}\right)$ of the phenalenoindole $\mathbf{6}$ in several solvents (cyclohexane, dioxane, chloroform, dimethylformamide, acetonitrile and ethanol; $\lambda_{\text {exc }}=$ $385 \mathrm{~nm})$. Inset: absorption spectrum of a solution $\left(2 \times 10^{-5} \mathrm{M}\right)$ of 6 in ethanol, as an example.

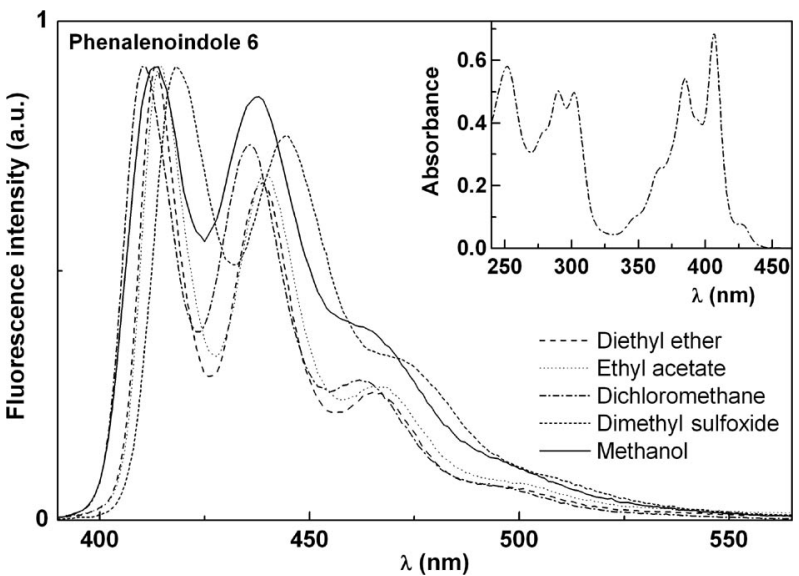

Figure 4. Normalized fluorescence spectra of solutions $\left(3 \times 10^{-6} \mathrm{M}\right)$ of the phenalenoindole $\mathbf{6}$ in several solvents (diethyl ether, ethyl acetate, dichloromethane, dimethylsulfoxide, and methanol; $\lambda_{\mathrm{exc}}=$ $385 \mathrm{~nm})$. Inset: absorption spectrum of a solution $\left(2 \times 10^{-5} \mathrm{M}\right)$ of 6 in dichloromethane.

$\bar{v}_{\mathrm{abs}}$ is the wavenumber of maximum absorption, $\bar{v}_{\mathrm{fl}}$ is the wavenumber of maximum emission, $\Delta \mu=\mu^{\mathrm{e}}-\mu^{\mathrm{g}}$ is the difference in the dipole moment of the solute molecule between excited $\left(\mu_{\mathrm{e}}\right)$ and ground $\left(\mu_{\mathrm{g}}\right)$ states, $R$ is the cavity radius (considering the fluorophore a point dipole at the centre of a spherical cavity immersed in the homogeneous solvent), and $\Delta f$ is the orientation polarizability given by Equation (2) where $\varepsilon$ is the static dielectric constant and $n$ the refractive index of the solvent.

$\Delta f=\frac{\varepsilon-1}{2 \varepsilon+1}-\frac{n^{2}-1}{2 n^{2}+1}$

Lippert-Mataga plots for compounds $\mathbf{5}$ and $\mathbf{6}$, shown in Figure 5, are reasonably linear, but with alcohols and chloroform exhibiting large positive deviations, more pronounced for the pyrenylindole $\mathbf{5}$. This behaviour in alcohols and chloroform can be due to specific solute-solvent inter- 
actions through hydrogen bonds. The formation of hydrogen bonds between chloroform and proton acceptors has been known for a long time. ${ }^{[22]}$ The two compounds have the capability for hydrogen bond formation through their ester groups (acceptors) and their NH groups (donors).

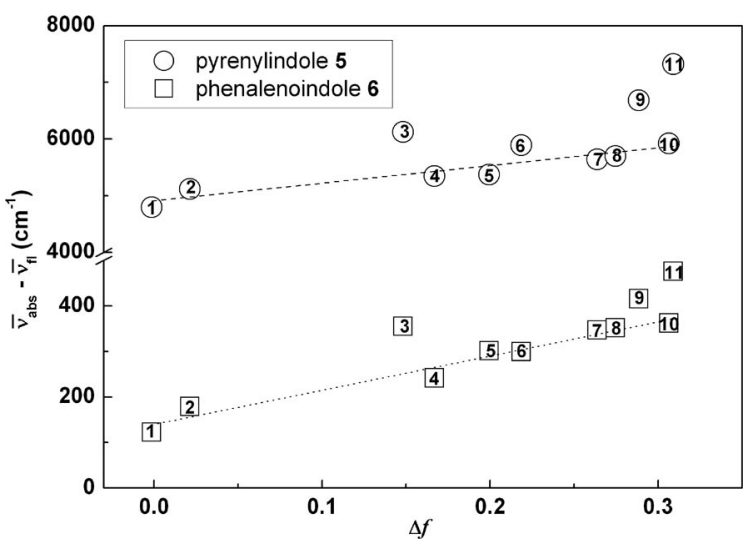

Figure 5. Lippert-Mataga plots for compounds 5 and 6: 1) cyclohexane, 2) dioxane, 3) chloroform, 4) diethyl ether, 5) ethyl acetate, 6) dichloromethane, 7) dimethyl sulfoxide, 8) dimethylformamide, 9) ethanol, 10) acetonitrile, 11) methanol (values of $\varepsilon$ and $n$ were obtained from ref. ${ }^{[23]}$ ).

From ab initio molecular quantum chemistry calculations, the cavity radii $(R)$ and the ground state dipole moments $\left(\mu_{\mathrm{g}}\right)$ for the two compounds were determined (Table 2) through optimized structures produced with GAMESS software ${ }^{[24]}$ and use of a 3-21G(d) basis set ${ }^{[25]}$ (Figure 6). The optimized geometry of the pyrenylindole 5 shows the indole ring almost perpendicular to the pyrene moiety, with the ester group in close proximity to it. The phenalenoindole $\mathbf{6}$ is completely planar, with the ester group in the same plane as the aromatic rings (Figure 6).

Table 2. Cavity radii $(R)$ and ground state dipole moments $\left(\mu_{\mathrm{g}}\right)$ obtained from theoretical calculations, together with excited state dipole moments $\left(\mu_{\mathrm{e}}\right)$ calculated from the Lippert-Mataga plots.

\begin{tabular}{llll}
\hline & $\begin{array}{l}\text { Cavity } \\
\text { radius, } R[\AA]\end{array}$ & $\begin{array}{l}\text { Ground state dipole } \\
\text { moment, } \mu_{\mathrm{g}}[\mathrm{D}]\end{array}$ & $\begin{array}{l}\text { Excited state dipole } \\
\text { moment, } \mu_{\mathrm{e}}[\mathrm{D}]\end{array}$ \\
\hline $\mathbf{5}$ & 8.2 & 0.61 & 13.7 \\
$\mathbf{6}$ & 7.5 & 0.94 & 6.5 \\
\hline
\end{tabular}
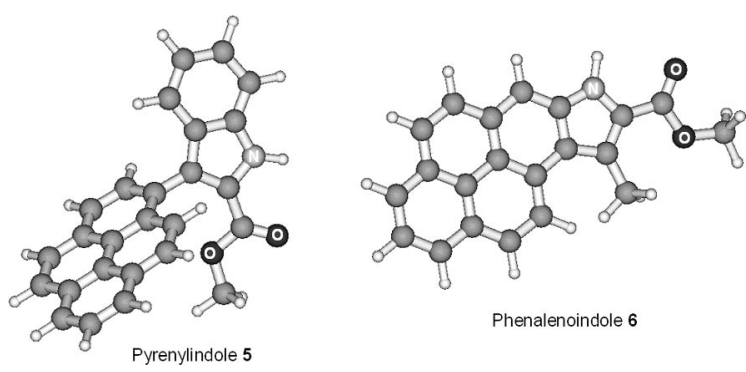

Figure 6. Optimized structures of the pyrenylindole $\mathbf{5}$ and phenalenoindole 6 (obtained with GAMESS software), with indication of $\mathrm{N}$ and $\mathrm{O}$ atoms.
The excited state dipole moments, estimated from the Lippert-Mataga plots, are presented in Table 2. The $\mu_{\mathrm{e}}$ value of compound 5 points to the presence of a strong charge-transfer mechanism in the excited state. The HOMO electronic wavefunction of the pyrenylindole (Figure 7) is mainly localized on the pyrene moiety, extending to the $\mathrm{N}$ atom of the pyrrole ring. The HOMO-LUMO transition shows a charge transfer to the carbonyl group of the ester, with a slight decrease in the electron density on the $\mathrm{N}$ atom. However, this does not seem sufficient to justify the high $\mu_{\mathrm{e}}$ value obtained from the Lippert-Mataga plot. A higher charge-transfer character could be attained by geometrical relaxation in the excited state, leading to a flattening of the molecule (mesomeric intramolecular charge transfer, MICT), as observed for a diester derivative of 1-phenylpyrene. ${ }^{[16,26]}$ Twisted intramolecular charge transfer (TICT) states usually exhibit significantly higher excited state dipole moments $(\geq 20 \mathrm{D})^{[27]}$ than the value obtained for compound 5. The HOMO electronic wavefunction of the phenalenoindole 6 (Figure 7) is mainly localized on the aromatic ring system, with a small contribution from the oxygen atoms of the carboxylate group. A slight increase in the electronic densities on both oxygen atoms is the main feature of the HOMO-LUMO transition, confirming a low CT character of the excited state.
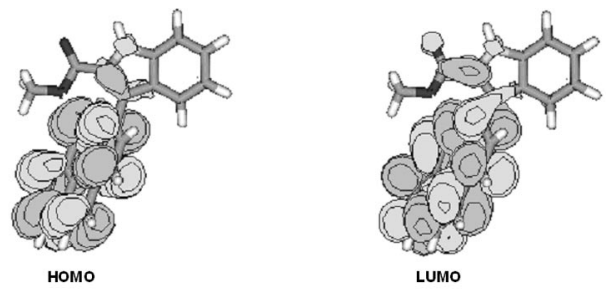

Pyrenylindole 5
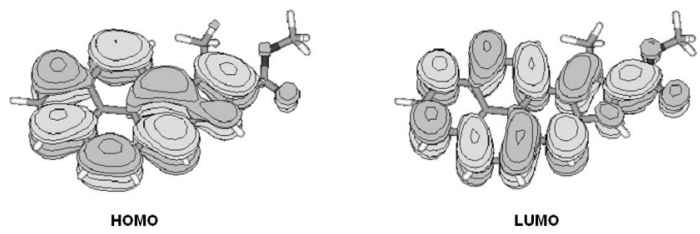

Phenalenoind ole 6

Figure 7. HOMO and LUMO electronic wavefunctions of the pyrenylindole $\mathbf{5}$ and the phenalenoindole $\mathbf{6}$.

Both compounds present high fluorescence quantum yields in almost all solvents, ca. $80 \%$ being attained in some polar nonprotic solvents (Table 1). This result shows that the cyclizations of the parent compounds (Z)-3 and (Z)4 were successful in producing molecules that are highly fluorescent in environments of different polarities. The $\Phi_{\mathrm{F}}$ value here obtained for the methyl 9-methylphenalenoindole-8-carboxylate (6) in ethyl acetate is in total agreement with that reported for a similar compound in the same solvent. ${ }^{[3 \mathrm{~d}]}$ In alcohols, especially in methanol, the pyrenylindole 5 exhibits a significant diminution in its $\Phi_{\mathrm{F}}$ value, probably caused by an increase in singlet $\rightarrow$ triplet intersystem crossing efficiency through $\mathrm{H}$-bond interaction, as im- 
plied by the positive deviations observable in the LippertMataga plot. However, the same effect in $\Phi_{\mathrm{F}}$ is not perceptible either for compound $\mathbf{5}$ in chloroform or for compound 6.

The high fluorescence quantum yields and solvent-sensitive emissions of compounds $\mathbf{5}$ and $\mathbf{6}$ make them strong candidates as fluorescence probes for biological membranes and proteins, because they can be excited without simultaneous excitation of tryptophan and other aromatic amino acids (tyrosine and phenylalanine) in proteins, which absorb light at $\lambda<300 \mathrm{~nm}^{.20]}$

Figure 8 displays the emission spectra of the peptide containing the pyrenylindole moiety $\mathbf{8}$ in ethanol and in phosphate buffer ( $\mathrm{pH}$ 8.0). Absorption spectra of the peptide are displayed as insets. Maximum absorption and emission wavelengths, molar extinction coefficients and fluorescence quantum yield values are presented in Table 3 .

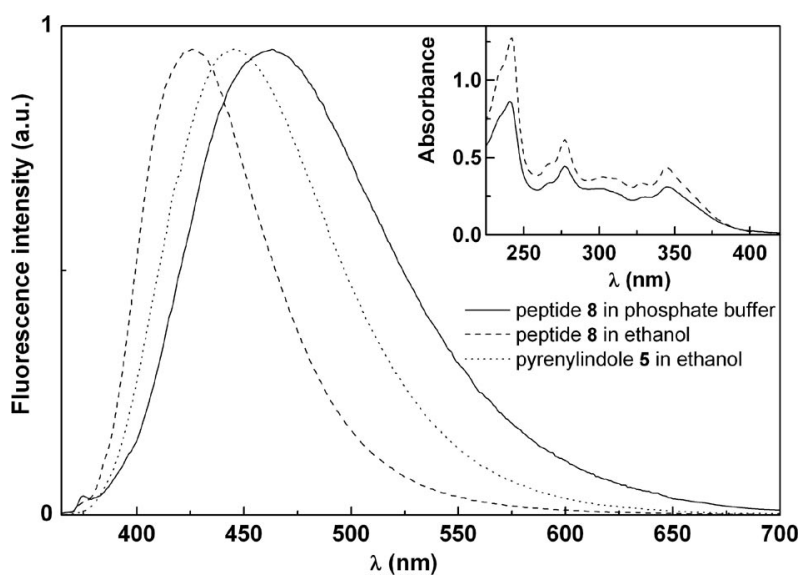

Figure 8. Normalized fluorescence spectra $\left(\lambda_{\mathrm{exc}}=345 \mathrm{~nm}\right)$ of solutions $\left(2 \times 10^{-6} \mathrm{M}\right)$ of compound $\mathbf{8}$ in ethanol and in phosphate buffer ( $1 \mathrm{~mm}, \mathrm{pH} 8)$. Emission of the pyrenylindole $\mathbf{5}$ in ethanol is also shown for comparison. Inset: absorption spectra of solutions $\left(2 \times 10^{-5} \mathrm{M}\right)$ of $\mathbf{8}$ in ethanol and in phosphate buffer.

Table 3. Maximum absorption $\left(\lambda_{\text {abs }}\right)$ and emission wavelengths $\left(\lambda_{\text {em }}\right)$, molar extinction coefficients $(\varepsilon)$ and fluorescence quantum yields $\left(\Phi_{\mathrm{F}}\right)$ for compound $\mathbf{8}$.

\begin{tabular}{llll}
\hline Solvent & $\begin{array}{l}\lambda_{\mathrm{abs}}[\mathrm{nm}](\varepsilon \\
\left.\left[10^{4} \mathrm{M}^{-1} \mathrm{~cm}^{-1}\right]\right)\end{array}$ & $\begin{array}{l}\lambda_{\mathrm{em}} \\
{[\mathrm{nm}]}\end{array}$ & $\Phi_{\mathrm{F}}{ }^{[\mathrm{a}]}$ \\
\hline Ethanol & $345(1.99), 302(1.70)$, & 426 & 0.85 \\
& $277(2.80), 242(5.80)$ & & \\
Phosphate & $345(1.56), 301(1.49)$, & 463 & $0.49^{[\mathrm{b}]}$ \\
buffer & $277(2.22), 241(4.32)$ & & \\
$(1 \mathrm{~mm}, \mathrm{pH}=8.0)$ & & &
\end{tabular}

[a] Relative to anthracene in ethanol $\left(\Phi_{\mathrm{F}}=0.27\right.$ at $\left.25^{\circ} \mathrm{C}\right)\left[{ }^{[18]}\right.$ Error about $10 \%$. [b] Non-deoxygenated solution.

The absorption spectra of the peptide are similar to those of pyrenylindole 5, with slightly lower extinction coefficients and a very small red shift in ethanol. However, the emission of the peptide in ethanol presents a significant blue shift and narrower band [half width at half maximum $(\mathrm{HWHM})=1800 \mathrm{~cm}^{-1}$ ] relative to that of pyrenylindole $\mathbf{5}$ $\left(\mathrm{HWHM}=2205 \mathrm{~cm}^{-1}\right)$. The fluorescence quantum yield in ethanol increases to $85 \%$, despite the peptide chain at- tached to the pyrenylindole moiety, which could increase nonradiative deactivation processes. This behaviour points to a lower CT character of the excited state in compound 8 , with a diminution of the Stokes shift in ethanol $\left(5500 \mathrm{~cm}^{-1}\right.$ for the peptide and $6700 \mathrm{~cm}^{-1}$ for the pyrenylindole). This could be mainly due to the removal of the ester group in the $\beta$-position relative to the pyrene system, which has been shown markedly to influence the photophysical behaviour of phenylpyrene compounds, increasing the excited state CT character and lowering the fluorescence quantum yield. ${ }^{[16]}$ The small peak observed at the higherenergy side (at $375 \mathrm{~nm}$ ) of the peptide emission (more perceptible in phosphate buffer) indicates that there is a residual contribution from the locally excited (LE) state.

Despite the lessening of the excited state CT character relative to the pyrenylindole, the emission of the peptide remains very sensitive to solvent (Figure 8), exhibiting a significantly red-shifted and broader band, relative to ethanol, in phosphate buffer. The fluorescence quantum yield is high, even in aqueous non-deoxygenated solution (Table 3 ).

The fluorescence emission of the peptide $\mathbf{8}$ in phosphate buffer (1 mM) was also recorded as a function of compound concentration (Figure 9) over a range of three orders of magnitude (between $1 \times 10^{-8} \mathrm{M}$ and $1 \times 10^{-5} \mathrm{M}$ ). It could be verified that the fluorescence intensity is proportional to the concentration and that the normalized spectra perfectly overlap (inset of Figure 9), which shows that no aggregation of the compound $\mathbf{8}$ molecules occurs in this concentration range. These results point to promising potential utility of the pyrenylindole as a fluorescence label for peptides and proteins, avoiding the aggregation propensity of pyrene. ${ }^{[28]}$

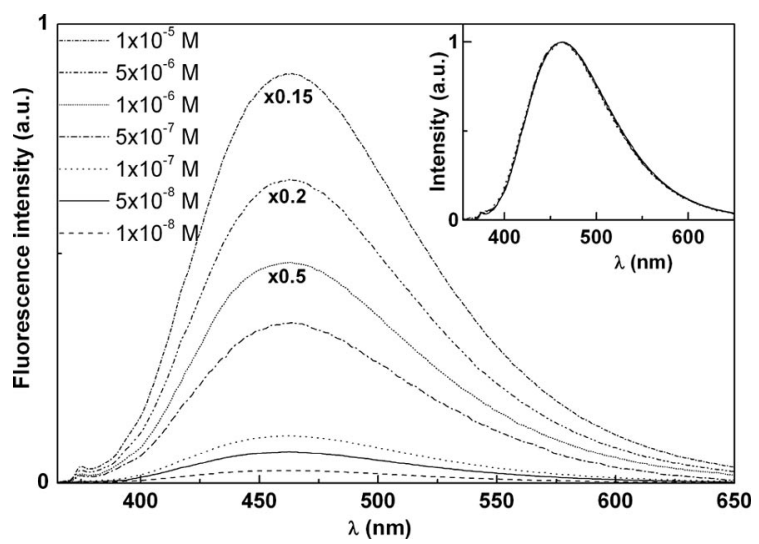

Figure 9. Fluorescence spectra of solutions of compound $\mathbf{8}$ in phosphate buffer $(\mathrm{pH} 8)$ over the concentration range between $1 \times 10^{-8} \mathrm{M}$ and $1 \times 10^{-5} \mathrm{M}\left(\lambda_{\mathrm{exc}}=345 \mathrm{~nm}\right)$. Inset: corresponding normalized emission spectra.

Photophysical studies of the two compounds 5 and $\mathbf{6}$ incorporated in lipid aggregates were also performed. Different types of phospholipid molecule components of biological membranes - DPPC, DPPG, egg PC and DOPE were used for vesicle preparation. It is known that, at room temperature, the neutral (zwitterionic) phospholipid DPPC (16:0 PC) and the anionic DPPG (16:0 PG) exist in the ordered gel phase, in which the hydrocarbon chains are fully 
extended and closely packed. Above the melting transition temperature $-T_{\mathrm{m}}=41{ }^{\circ} \mathrm{C}^{[29]}$ for DPPC and $T_{\mathrm{m}}=39.6^{\circ} \mathrm{C}^{[30]}$ for DPPG - lipid chains attain the disordered liquid-crystalline phase. DOPE (18:1 PE) has a very low melting transition temperature $\left(T_{\mathrm{m}}=-16^{\circ} \mathrm{C}\right)^{[31]}$ and presents a phase transition from lamellar bilayer to inverse hexagonal $\left(\mathrm{L}_{\alpha}-\right.$ $\left.\mathrm{H}_{\text {II }}\right)$ at $3.3{ }^{\circ} \mathrm{C}^{[32]}$ Finally, egg PC is a natural phospholipid mixture, in which all molecules have the same polar head group (phosphatidylcholine) but several hydrocarbon chains, differing in length and degree of unsaturation. The main components of egg PC are 16:0 PC, 18:0 PC and 18:1 PC. ${ }^{[33]}$ Therefore, at room temperature, egg PC is in the fluid liquid-crystalline phase.

The emission spectra of compounds 5 and $\mathbf{6}$ in lipid membranes are displayed in Figures 10 and 11. The insets of these figures show the emission spectra of both compounds in cyclohexane and in ethanol at $55^{\circ} \mathrm{C}$. In homogeneous solution, the effect of increasing temperature (from $25-55^{\circ} \mathrm{C}$ ) on the fluorescence of these molecules is a ca. $20 \%$ reduction in intensity and a very small blue shift $(2 \mathrm{~nm}$ for compound $\mathbf{5}$ and $1 \mathrm{~nm}$ for compound $\mathbf{6}$ ). It can also be observed that the spectral shapes at $55^{\circ} \mathrm{C}$ and $25^{\circ} \mathrm{C}$ are roughly the same.

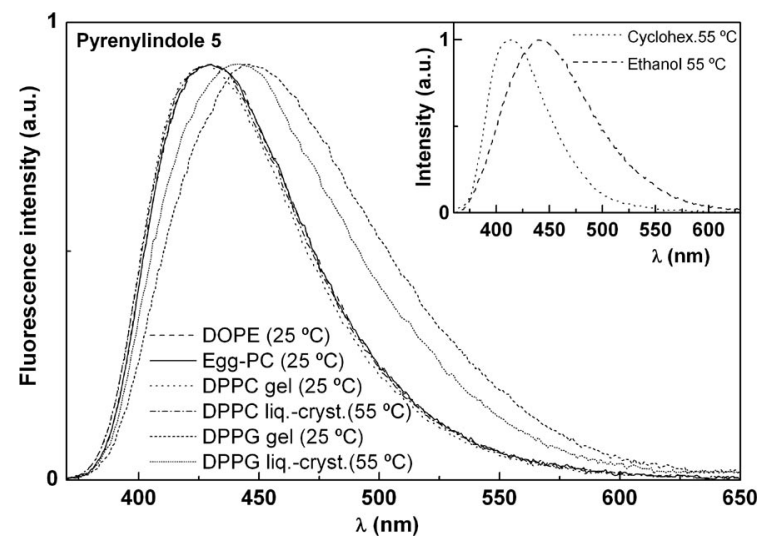

Figure 10. Normalized fluorescence spectra of the pyrenylindole 5 $\left(2 \times 10^{-6} \mathrm{M}\right)$ in lipid membranes of DOPE, egg PC, DPPC and DPPG $\left(\lambda_{\text {exc }}=345 \mathrm{~nm}\right)$. Inset: normalized fluorescence spectra of compound $\mathbf{5}$ in cyclohexane and ethanol at $55^{\circ} \mathrm{C}$.

The fluorescence spectra of the pyrenylindole 5 are similar in almost all lipid aggregates, except in DPPG. The emission maxima in egg PC, DPPC and DOPE (Table 4) are similar to the value in $N, N$-dimethylformamide (Table 1), indicating an average environment of moderate polarity. In DPPG membranes, however, the emission is broader and significantly red-shifted, especially in the rigid gel phase $\left(25^{\circ} \mathrm{C}\right)$. Because the difference between DPPC and DPPG molecules is only the polar head group, these results point to greater compaction of the lipid molecules in DPPC vesicles, with lower hydration levels. The results also show deeper penetration of the pyrenylindole 5 in DPPG vesicles in the fluid phase (relative to the gel phase), with relocation to the less hydrated environment.

The fluorescence quantum yield values (Table 4 ) at $25^{\circ} \mathrm{C}$ are high and similar in all lipid systems. In DPPC vesicles

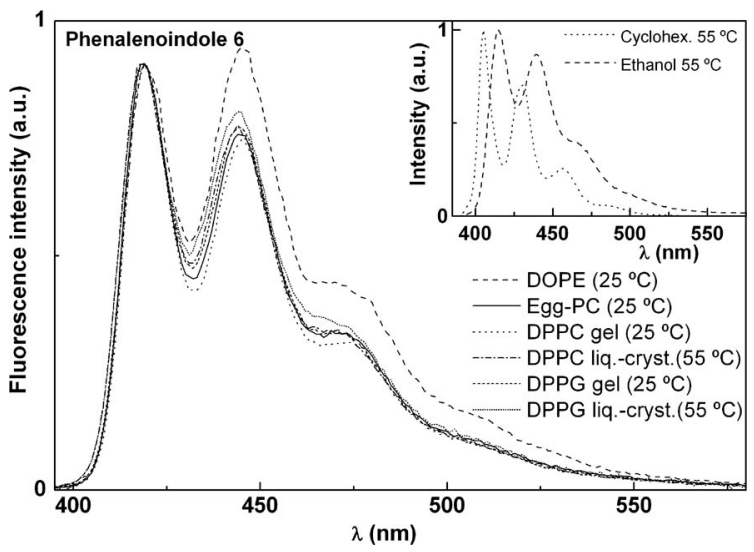

Figure 11. Normalized fluorescence spectra of the phenalenoindole $6\left(2 \times 10^{-6} \mathrm{M}\right)$ in lipid membranes of DOPE, egg PC, DPPC and DPPG $\left(\lambda_{\mathrm{exc}}=385 \mathrm{~nm}\right)$. Inset: normalized fluorescence spectra of compound 6 in cyclohexane and ethanol at $55^{\circ} \mathrm{C}$.

Table 4. Steady-state fluorescence anisotropy $(r)$ values, fluorescence quantum yields and maximum emission wavelengths $\left(\lambda_{\mathrm{em}}\right)$ of compounds 5 and $\mathbf{6}$ in lipid membranes (sh: shoulder). Values in ethylene glycol at room temperature are also shown for comparison.

\begin{tabular}{|c|c|c|c|c|c|c|}
\hline & \multicolumn{2}{|c|}{ Compound $\mathbf{5}$} & \multicolumn{4}{|c|}{ Compound 6} \\
\hline & $\Phi_{\mathrm{F}}^{[\mathrm{a}]}$ & $\begin{array}{l}\lambda_{\mathrm{em}} \\
{[\mathrm{nm}]}\end{array}$ & $r$ & $\Phi_{\mathrm{F}}^{[\mathrm{b}]}$ & $\lambda_{\mathrm{em}}[\mathrm{nm}]$ & $r$ \\
\hline $\begin{array}{l}\text { DOPE } \\
\left(25^{\circ} \mathrm{C}\right)\end{array}$ & 0.76 & 430 & 0.064 & 0.44 & $\begin{array}{l}420,447, \\
476 \mathrm{sh}\end{array}$ & 0.089 \\
\hline $\begin{array}{l}\mathrm{DPPC} \\
\left(25^{\circ} \mathrm{C}\right)\end{array}$ & 0.72 & 428 & 0.173 & 0.59 & $\begin{array}{l}420,446 \\
475 \mathrm{sh}\end{array}$ & 0.186 \\
\hline $\begin{array}{l}\mathrm{DPPC} \\
\left(55^{\circ} \mathrm{C}\right)\end{array}$ & 0.59 & 429 & 0.067 & 0.48 & $\begin{array}{l}420,445 \\
474 \mathrm{sh}\end{array}$ & 0.080 \\
\hline $\begin{array}{l}\operatorname{egg} \mathrm{PC} \\
\left(25^{\circ} \mathrm{C}\right)\end{array}$ & 0.74 & 430 & 0.097 & 0.66 & $\begin{array}{l}420,446 \\
474 \mathrm{sh}\end{array}$ & 0.130 \\
\hline $\begin{array}{l}\mathrm{DPPG} \\
\left(25^{\circ} \mathrm{C}\right)\end{array}$ & 0.72 & 448 & 0.127 & 0.58 & $\begin{array}{l}420,445 \\
474 \mathrm{sh}\end{array}$ & 0.141 \\
\hline $\begin{array}{l}\text { DPPG } \\
\left(55^{\circ} \mathrm{C}\right)\end{array}$ & 0.18 & 441 & 0.039 & 0.09 & $\begin{array}{l}420,445, \\
474 \mathrm{sh}\end{array}$ & 0.048 \\
\hline $\begin{array}{l}\text { ethylene } \\
\text { glycol } \\
\left(25^{\circ} \mathrm{C}\right)\end{array}$ & 0.61 & 472 & 0.093 & 0.63 & $\begin{array}{l}420,445 \\
472 \mathrm{sh}\end{array}$ & 0.092 \\
\hline
\end{tabular}

[a] Relative to anthracene in ethanol $\left(\Phi_{\mathrm{F}}=0.27\right.$ at $\left.25^{\circ} \mathrm{C}\right) \cdot{ }^{[18]}$ Error about $10 \%$. [b] Relative to 9,10 -diphenylanthracene in ethanol $\left(\Phi_{\mathrm{F}}\right.$ $=0.95$ at $\left.25^{\circ} \mathrm{C}\right) \cdot{ }^{[19]}$ Error about $10 \%$.

in the liquid-crystalline phase $\left(55^{\circ} \mathrm{C}\right)$ the decrease in $\Phi_{\mathrm{F}}$ is ca. $20 \%$, as observed in homogeneous solution. In DPPG vesicles at $55^{\circ} \mathrm{C}$, however, compound 5 displays a $75 \%$ decrease in its fluorescence quantum yield, indicating an increase in the nonradiative deactivation pathways relative to DPPC through, for example, hydrogen bonding between the pyrenylindole and the OH groups of DPPG polar head.

The fluorescence spectra of the phenalenoindole 6 are also roughly similar in almost all lipid aggregates (Figure 11), with constancy of the emission maxima values (Table 4), which are similar to that obtained in dimethyl sulfoxide (see Table 1). The main difference is observed in DOPE aggregates, in which the second and third emission peaks (the latter appearing as a shoulder) are more intense than in the other cases. It was observed (Figures 3 and 4) 
that the intensity ratio between the second $\left(I_{2}\right)$ and the first $\left(I_{1}\right)$ emission peaks increases with solvent polarity (the higher value was obtained in methanol, $I_{2} / I_{1}=0.93$ ). The behaviour observed in DOPE $\left(I_{2} / I_{1}=1.04\right)$ may indicate that compound $\mathbf{6}$ is located in a highly hydrated medium. It is known that the phospholipid DOPE, at room temperature, adopts the inverse hexagonal phase, in which the lipid molecules can adopt inverse curvature at the interface, allowing the chains to expand and at the same time reduce the headgroup area at the interface. ${ }^{[34]}$ In the self-organized DOPE aggregates, in which a quite different geometry is attained through the described chain expansion, a fraction of the molecules of compound $\mathbf{6}$ can be located in a waterrich environment. The fluorescence quantum yield at $25^{\circ} \mathrm{C}$ (Table 4) shows a decrease in DOPE relative to other lipids, in which the $\Phi_{\mathrm{F}}$ values are similar to those obtained in the majority of the solvents studied (see Table 1). One possible contribution to the lower $\Phi_{\mathrm{F}}$ value in DOPE would be the formation of hydrogen bonds between compound $\mathbf{6}$ and water in the highly hydrated environments. The formation of excimers could be another possibility for the spectral changes observed in DOPE, in view of a high local concentration of the phenalenoindole 6 in these aggregates. For the similar pyreno[2,1-b]pyrrole a weak excimer emission (with peak wavelength at ca. $510 \mathrm{~nm}$ ) was observed at $10^{-3} \mathrm{M}$ concentration in ethyl acetate. ${ }^{[3 \mathrm{~d}]}$

As observed for compound $\mathbf{5}$, the decrease in the $\Phi_{\mathrm{F}}$ values of compound 6 (ca. 17\%) in DPPC vesicles in the liquid-crystalline phase $\left(55^{\circ} \mathrm{C}\right)$ is similar to that in homogeneous solution. In DPPG vesicles at $55^{\circ} \mathrm{C}$, compound 6 (like compound 5) displays a strong decrease (ca. 84\%) in its fluorescence quantum yield. A slight increase in the $I_{2} / I_{1}$ peak ratio is also observed in DPPG fluid phase (Figure 11). Like the pyrenylindole $\mathbf{5}$, the phenalenoindole $\mathbf{6}$ also has the capacity to establish hydrogen bonds with the $\mathrm{OH}$ groups of the DPPG lipid polar head.

Fluorescence anisotropy measurements can give further information about the behaviour of these molecules in lipid membranes. The steady-state fluorescence anisotropy $(r)$ is given by Equation (3) where $I_{\mathrm{VV}}$ and $I_{\mathrm{VH}}$ are the intensities of the emission spectra obtained with vertical and horizontal polarization, respectively (for vertically polarized excitation light), and $G=I_{\mathrm{HV}} / I_{\mathrm{HH}}$ is the instrument correction factor, in which $I_{\mathrm{HV}}$ and $I_{\mathrm{HH}}$ are the emission intensities obtained with vertical and horizontal polarization (for horizontally polarized excitation light).

$r=\frac{I_{\mathrm{VV}}-G I_{\mathrm{VH}}}{I_{\mathrm{VV}}+2 G I_{\mathrm{VH}}}$

Steady-state anisotropy relates both to the excited-state lifetime and to the rotational correlation time of the fluorophore ${ }^{[35]}$ [Equation (4)] where $r_{0}$ is the fundamental anisotropy, $\tau$ is the excited-state lifetime and $\tau_{\mathrm{c}}$ is the rotational correlation time.

$\frac{1}{r}=\frac{1}{r_{0}}\left(1+\frac{\tau}{\tau_{\mathrm{c}}}\right)$
The fluorescence steady-state anisotropies determined for compounds $\mathbf{5}$ and $\mathbf{6}$ in lipid membranes are shown in Table 4. Anisotropy values and fluorescence quantum yields in ethylene glycol at room temperature, being similar for both molecules, were also determined for comparison.

For each compound the fluorescence quantum yields at $25^{\circ} \mathrm{C}$ are similar in all lipid aggregates, except for compound 6 in DOPE. Therefore, variations in fluorescence anisotropy values at this temperature can be directly related to changes in the rotational correlation time of the fluorophore and thus to changes in the microviscosity of the surrounding medium of the fluorescent molecule. The largest anisotropy values are observed in DPPC and DPPG in the gel phase $\left(25^{\circ} \mathrm{C}\right)$, especially in DPPC, which has a higher melting transition temperature than DPPG. The $r$ values are significantly lower in egg PC, which exists in the liquidcrystalline phase at room temperature, especially in the case of the pyrenylindole $\mathbf{5}$. The fluorescence anisotropies clearly indicate that both compounds are located inside the lipid bilayers. In DOPE, the chain expansion promoted by the inverse hexagonal phase ${ }^{[34]}$ can explain the small anisotropies determined.

As already mentioned, in DPPC and DPPG at $55^{\circ} \mathrm{C}-$ particularly in DPPG - fluorescence quenching is observed (Table 4). An increase in the steady-state anisotropy is predicted from a decrease in the excited-state lifetime [Equation (4)]. Both compounds show significant reductions in anisotropy at $55^{\circ} \mathrm{C}$, either in DPPC (around $60 \%$ ) or in DPPG (ca. 70\%), showing that these indolic derivatives clearly detect the phase transition from phospholipid gel to the liquid-crystalline state and the associated decrease in microviscosity. The anisotropy values of both compounds are always higher in DPPC than in DPPG, the $r_{\text {DPPC }} / r_{\text {DPPG }}$ ratio reaching 1.7 times at $55^{\circ} \mathrm{C}$. Although DPPG has a lower transition temperature, the difference between the $T_{\mathrm{m}}$ values of DPPC and DPPG is only $1.4^{\circ} \mathrm{C}$. It is possible that some compound molecules are located in hydrated environments in DPPG, near the polar head groups, which would explain a further decrease in fluorescence anisotropy. This is in accordance with the information obtained from the emission spectra and fluorescence quantum yield values.

\section{Conclusions}

Two new fluorescent compounds, a pyrenylindole-2-carboxylate and a phenalenoindole-8-carboxylate, were synthesized from the corresponding $\beta, \beta$-disubstituted dehydroalanine derivatives by metal-assisted $\mathrm{C}-\mathrm{N}$ intramolecular cyclizations and their photophysical behaviour was studied in solvents of different polarity. Each compound exhibits solvent-sensitive emission and high fluorescence quantum yields in all solvents studied. The pyrenylindole presents large red shifts in polar solvents due to a significant CT character of the excited state. The phenalenoindole displays smaller bathochromic shifts and a solvent-sensitive intensity ratio between the two main emission peaks.

The pyrenylindole moiety was inserted into a peptide by a solid-phase strategy. The pyrenylindole-peptide exhibits 
fluorescence emission that is sensitive to the environment and high fluorescence quantum yields, even in non-deoxygenated aqueous media.

The pyrenylindole and the phenalenoindole were also incorporated in lipid aggregates of DPPC, DPPG, DOPE and egg PC. Steady-state fluorescence anisotropy measurements revealed that both compounds are located inside the lipid bilayers and are able to report clearly the transition between the gel and liquid-crystalline phases.

These results point to promising potential utility of these compounds as fluorescence probes for biological systems, either as extrinsic probes or as labels covalently bound to biomolecules.

\section{Experimental Section}

Materials and Methods: Melting points $\left({ }^{\circ} \mathrm{C}\right)$ were determined in a Gallenkamp apparatus and are uncorrected. ${ }^{1} \mathrm{H}$ and ${ }^{13} \mathrm{C} \mathrm{NMR}$ spectra were recorded on a Varian Unity Plus instrument at 300 and $75.4 \mathrm{MHz}$, respectively and on a Bruker Avance $\mathrm{II}^{+}$instrument at 400 and $100.6 \mathrm{MHz}$, respectively. Chemical shifts are given in ppm and coupling constants in $\mathrm{Hz}$. Heteronuclear correlations $\left({ }^{1} \mathrm{H}-\right.$ ${ }^{13} \mathrm{C}, \mathrm{HMQC}$ and HMBC) were also preformed. HRMS (EI or ESI) data were recorded by the mass spectrometry service of the University of Vigo, Spain. Elemental analysis was performed on a LECO CHNS 932 elemental analyser.

The reactions were monitored by thin-layer chromatography (TLC). Column chromatography was performed on Macherey-Nagel silica gel (230-400 mesh). Petroleum ether had a boiling range of $40-60{ }^{\circ} \mathrm{C}$. When a solvent gradient was used, the increase in polarity was made from neat petroleum ether to mixtures of diethyl ether/petroleum ether, increasing $10 \%$ of diethyl ether each time, until the isolation of the product. $\mathrm{PdCl}_{2} \mathrm{dppf} \cdot \mathrm{CH}_{2} \mathrm{Cl}_{2}$ (1:1) refers to the $\left[1,1^{\prime}\right.$-bis(diphenylphosphanyl)ferrocene]-dichloropalladium(II) complex with dichloromethane.

All the solutions were prepared with spectroscopic grade solvents and ultrapure water (Milli-Q grade). 1,2-Dipalmitoyl-sn-glycero-3phosphocholine (DPPC), 1,2-dioleoyl-sn-glycero-3-phosphoethanolamine (DOPE), 1,2-diacyl-sn-glycero-3-phosphocholine from egg yolk (egg PC) and 1,2-dipalmitoyl-sn-glycero-3-[phospho-rac-(1glycerol)] (sodium salt) (DPPG) were purchased from Sigma-Aldrich (lipid structures are shown below).

For preparation of DOPE and egg PC membranes, defined volumes of stock solutions of lipid (26.9 mM for DOPE and $34.5 \mathrm{~mm}$ for egg PC) and compound ( $0.197 \mathrm{~mm}$ for $\mathbf{5}$, and $0.195 \mathrm{~mm}$ for $\mathbf{6})$ in ethanol were injected together, at room temperature and with vigorous stirring, to an aqueous buffer solution [Tris (10 mM), EDTA (1 mM), $\mathrm{pH}$ 7.4]. A similar procedure was adopted for DPPC and DPPG vesicles, but the injection of the required amounts of stock solutions of lipid (50 mM in ethanol for DPPC and $13.4 \mathrm{~mm}$ in tetrahydrofuran for DPPG) and compounds 5 or $\mathbf{6}$ was done at $60^{\circ} \mathrm{C}$, well above the melting transition temperatures of DPPC (ca. $41^{\circ} \mathrm{C}$ ) ${ }^{[29]}$ and DPPG $\left(39.6^{\circ} \mathrm{C}\right) .{ }^{[30]}$ In each case the final lipid concentration was $1 \mathrm{~mm}$, with compounds 5 or $\mathbf{6} /$ lipid molar ratio of 1:500.

Absorption spectra were recorded with a Shimadzu UV-3101PC UV/Vis/NIR spectrophotometer. Fluorescence measurements were performed with a Spex Fluorolog 3 spectrofluorimeter, fitted with double monochromators both in excitation and in emission, GlanThompson polarizers and a temperature-controllable cuvette
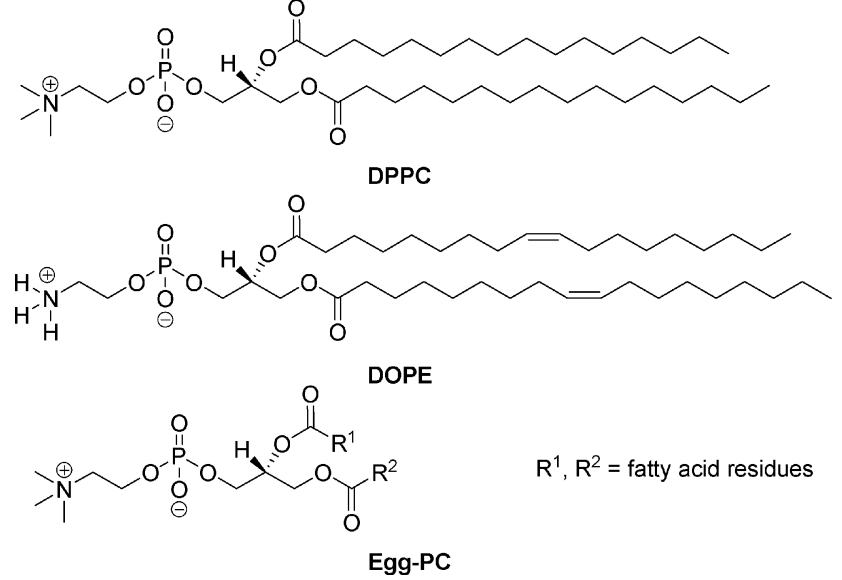<smiles>CCCCCCCCCCCCCCCCCCCCCCCC(=O)OC[C@H](COP(=O)([O-])OCC(O)CO)OC(=O)CCCCCC</smiles>

holder. Fluorescence spectra were corrected for the instrumental response of the system.

For fluorescence quantum yield determination, the solutions were first bubbled for $60 \mathrm{~min}$ with ultrapure nitrogen. The fluorescence quantum yields $\left(\Phi_{\mathrm{s}}\right)$ were determined by the standard method [Equation (5)]..$^{[36,37]}$ Anthracene in ethanol $\left(\Phi_{\mathrm{r}}=0.27^{[18]}\right)$ and 9,10diphenylanthracene in ethanol $\left(\Phi_{\mathrm{r}}=0.95^{[19]}\right)$ were used as reference for compounds $\mathbf{5}$ and $\mathbf{6}$, respectively,

$\Phi_{\mathrm{S}}=\frac{A_{\mathrm{r}} F_{\mathrm{S}} n_{\mathrm{S}}^{2}}{A_{\mathrm{S}} F_{\mathrm{r}} n_{\mathrm{r}}^{2}} \Phi_{\mathrm{r}}$

where $A$ is the absorbance at the excitation wavelength, $F$ the integrated emission area and $n$ the refraction index of the solvents used. Subscripts refer to the reference (r) or sample (s) compound.

Synthesis: Compounds 1, 2, (Z)-3 and (Z)-4 were prepared by procedures described elsewhere. ${ }^{[6,38]}$

Synthesis of Compound 5: $\mathrm{Pd}(\mathrm{OAc})_{2}(50 \mathrm{~mol}-\%)$ and $\mathrm{Cu}(\mathrm{OAc})_{2}$ (3 equiv.) were added to a solution of compound (Z)-3 (0.25 mmol, $115.6 \mathrm{mg})$ in DMF $(0.1 \mathrm{M})$. The reaction mixture was kept at $160{ }^{\circ} \mathrm{C}$ under argon and the course of the reaction was followed by TLC. When all of the dehydroamino acid had been consumed, ethyl acetate $(30 \mathrm{~mL})$ was added to the reaction mixture. The organic layer was washed with $\mathrm{KHSO}_{4}(1 \mathrm{M}, 3 \times 30 \mathrm{~mL}), \mathrm{NaHCO}_{3}(1 \mathrm{M}$, $3 \times 30 \mathrm{~mL})$ and brine $(3 \times 30 \mathrm{~mL})$ and dried with $\mathrm{MgSO}_{4}$. The solvent was removed under reduced pressure and the oil obtained was subjected to column chromatography with diethyl ether/petroleum ether (1:3) to give a white solid $(90.0 \%, 84.4 \mathrm{mg})$; m.p. $201-202{ }^{\circ} \mathrm{C}$ (diethyl ether $/ n$-hexane). ${ }^{1} \mathrm{H}$ NMR (400 MHz, $\mathrm{CDCl}_{3}$ ): $\delta=3.59$ (s, $3 \mathrm{H}, \mathrm{CH}_{3} \mathrm{OMe}$ ), 7.09-7.13 (m, $\left.1 \mathrm{H}, \mathrm{ArH}\right), 7.31(\mathrm{~d}, J=8.0 \mathrm{~Hz} 1$ $\mathrm{H}, \mathrm{ArH}), 7.42(\mathrm{t}, J=8.0 \mathrm{~Hz}, 1 \mathrm{H}, \mathrm{ArH}), 7.57(\mathrm{~d}, J=7.6 \mathrm{~Hz}, 1 \mathrm{H}$, ArH), 7.89-7.97 (m, $2 \mathrm{H}, \mathrm{ArH}), 8.02$ (t $J=7.6 \mathrm{~Hz}, 1 \mathrm{H}, \mathrm{ArH})$, $8.08(\mathrm{~d}, J=8.0 \mathrm{~Hz}, 1 \mathrm{H}, \mathrm{ArH}), 8.13-8.18(\mathrm{~m}, 3 \mathrm{H}, \mathrm{ArH}), 8.23$ (d, $J=7.6 \mathrm{~Hz}, 1 \mathrm{H}, \mathrm{ArH}), 8.28$ (d, $J=8.0 \mathrm{~Hz}, 1 \mathrm{H}, \mathrm{ArH}), 9.32$ (br. s, $1 \mathrm{H}, \mathrm{NH})$ ppm. ${ }^{13} \mathrm{C} \mathrm{NMR}\left(400 \mathrm{MHz}, \mathrm{CDCl}_{3}\right): \delta=51.77\left(\mathrm{OCH}_{3}\right)$, $111.84(\mathrm{CH}), 121.02(\mathrm{CH}), 122.61(\mathrm{CH}), 122.62(\mathrm{C}), 124.30(\mathrm{CH})$, $124.30(\mathrm{C}), 124.84(\mathrm{C}), 124.92(\mathrm{CH}), 125.03(\mathrm{CH}), 125.86(\mathrm{CH})$, $125.96(\mathrm{CH}), 127.09(\mathrm{CH}), 127.39(\mathrm{CH}), 127.49(\mathrm{CH}), 129.03(\mathrm{CH})$, 
129.08 (C), 129.19 (C), 129.93 (C), 130.85 (C), 131.03 (C), 131.36 (C), 135.79 (C), $162.53(\mathrm{C}=\mathrm{O}) \mathrm{ppm}$. HRMS (TOF): calcd. for $\mathrm{C}_{26} \mathrm{H}_{17} \mathrm{NO}_{2}$ 375.1259; found 375.1259.

Synthesis of Compound 6: $\mathrm{Pd}(\mathrm{OAc})_{2}(50 \mathrm{~mol}-\%)$ and $\mathrm{Cu}(\mathrm{OAc})_{2}$ (3 equiv.) were added to a solution of compound $(Z)-4(0.25 \mathrm{mmol}$, $100 \mathrm{mg})$ in DMF $(0.1 \mathrm{M})$. The reaction mixture was kept at $160{ }^{\circ} \mathrm{C}$ under argon and the course of the reaction was followed by TLC. When all of the dehydroamino acid had been consumed, ethyl acetate $(30 \mathrm{~mL})$ was added to the reaction mixture. The organic layer was washed with $\mathrm{KHSO}_{4}(1 \mathrm{M}, 3 \times 30 \mathrm{~mL}), \mathrm{NaHCO}_{3}(1 \mathrm{M}$, $3 \times 30 \mathrm{~mL})$ and brine $(3 \times 30 \mathrm{~mL})$ and dried with $\mathrm{MgSO}_{4}$. The solvent was removed under reduced pressure and the oil obtained was subjected to column chromatography with ether/petroleum ether (1:3) to give a white solid $(36.0 \%, 28.2 \mathrm{mg})$; m.p. $102-103{ }^{\circ} \mathrm{C}$ (diethyl ether $/ n$-hexane). ${ }^{1} \mathrm{H}$ NMR (400 MHz, $\mathrm{CDCl}_{3}$ ): $\delta=3.29$ (s, 3 $\left.\mathrm{H}, \mathrm{CH}_{3}\right), 4.05$ (s, $3 \mathrm{H}, \mathrm{CH}_{3} \mathrm{OMe}$ ), 7.93-7.50 (m, $\left.3 \mathrm{H}, \mathrm{ArH}\right), 8.08$ (s, $1 \mathrm{H}, \mathrm{ArH}), 8.12(\mathrm{~d}, J=7.6 \mathrm{~Hz}, 1 \mathrm{H}, \mathrm{ArH}), 8.23(\mathrm{~d}, J=7.6 \mathrm{~Hz}$, $1 \mathrm{H}, \operatorname{ArH}), 8.28(\mathrm{~d}, J=9.2 \mathrm{~Hz}, 1 \mathrm{H}, \operatorname{ArH}), 8.97(\mathrm{~d}, J=9.2 \mathrm{~Hz}, 1$ $\mathrm{H}, \mathrm{ArH}), 9.19$ (br. s, $1 \mathrm{H}, \mathrm{NH}) \mathrm{ppm} .{ }^{13} \mathrm{C} \mathrm{NMR}\left(400 \mathrm{MHz}, \mathrm{CDCl}_{3}\right)$ : $\delta=13.65\left(\mathrm{CH}_{3}\right), 51.84\left(\mathrm{OCH}_{3}\right), 108.15(\mathrm{CH}), 120.90(\mathrm{C}), 122.08$ (C), $122.54(\mathrm{C}), 123.20(\mathrm{CH}), 123.79(\mathrm{C}), 124.78(\mathrm{CH}), 124.86$ $(\mathrm{CH}), 125.31(\mathrm{CH}), 125.67(\mathrm{C}), 127.24(\mathrm{C}), 127.35(\mathrm{CH}), 127.71$ $(\mathrm{CH}), 127.85(\mathrm{CH}), 130.10(\mathrm{C}), 130.52(\mathrm{C}), 130.77(\mathrm{C}), 134.37(\mathrm{C})$, $162.88(\mathrm{C}=\mathrm{O}) \mathrm{ppm}$. HRMS (TOF): calcd. for $\mathrm{C}_{21} \mathrm{H}_{15} \mathrm{NO}_{2}$ 313.1103; found 313.1108

Synthesis of Compound 7: $\mathrm{NaOH}(1 \mathrm{M}, 3$ equiv.) was added to a solution of compound $5(150 \mathrm{mg}, 0.40 \mathrm{mmol})$ in methanol $\left(0.1 \mathrm{moldm}^{-3}\right)$, and the mixture was heated at reflux. When all of the reagent had been consumed $(6 \mathrm{~h})$, the ethanol was removed and the solution was acidified to $\mathrm{pH} 1-2$ with $\mathrm{HCl}(5 \mathrm{M})$. Filtration of the solid formed afforded compound 7 (120 mg, 83\%); m.p. 167.0 $168.0^{\circ} \mathrm{C} .{ }^{1} \mathrm{H}$ NMR $\left(400 \mathrm{MHz}, \mathrm{CDCl}_{3}\right): \delta=7.01-7.24(\mathrm{~m}, 5 \mathrm{H}$, ArH), 7.62-8.27 (s, 8 H, ArH), 9.26 (br. s, $1 \mathrm{H}, \mathrm{NH}) \mathrm{ppm} .{ }^{13} \mathrm{C}$ NMR $\left(400 \mathrm{MHz}, \mathrm{CDCl}_{3}\right): \delta=112.01(\mathrm{CH}), 120.86(\mathrm{CH}), 122.04$ $(\mathrm{CH}), 124.26(\mathrm{CH}), 124.66(\mathrm{C}), 124.90(\mathrm{CH}), 125.73(\mathrm{CH}), 126.04$ $(\mathrm{CH}), 127.08(\mathrm{CH}), 127.20(\mathrm{CH}), 128.43(\mathrm{CH}), 128.77(\mathrm{C}), 129.07$ $(\mathrm{CH}), 129.76(\mathrm{C}), 130.60(\mathrm{CH}), 130.72(\mathrm{C}), 130.86(\mathrm{C}), 131.12(\mathrm{C})$, $131.21(\mathrm{C}), 133.02(\mathrm{C}), 133.05(\mathrm{C}), 133.15(\mathrm{CH}), 135.94(\mathrm{C}), 138.71$ (C), $166.07 \quad(\mathrm{C}=\mathrm{O}) \mathrm{ppm}$. HRMS (micrOTOF): calcd. for $\mathrm{C}_{25} \mathrm{H}_{16} \mathrm{NO}_{2} 362.11810[\mathrm{M}+\mathrm{H}]^{+}$; found 362.11758 .

Synthesis of Compound 8: The AGAG peptide was prepared by solid-phase synthesis. Fmoc-Gly-OH (1.2 equiv.) and diisopropylethylamine (DIPEA, 4 equiv. relative to the amino acid) in dry dichloromethane (DCM) were added to the 2-chlorotrityl chloride resin $(0.5 \mathrm{~g})$. The mixture was left stirring for $2 \mathrm{~h}$. At end of this time the resin was washed with a mixture of DCM/MeOH/DIPEA $(17: 2: 1)(3 \times 20 \mathrm{~mL})$, DMF $(2 \times 20 \mathrm{~mL})$ and DCM $(2 \times 20 \mathrm{~mL})$. The resin was dried in vacuo and the determination of the first residue attachment was carried out by cleaving Fmoc with piperidine and measuring the solution concentration of dibenzofulvene by UV spectroscopy. The degree of loading was $0.33 \mathrm{molg}^{-1}$. After cleavage of the Fmoc group with a solution of piperidine in DMF, couplings were carried out with use of an excess of the Fmocamino acid (4 equiv., $0.50 \mathrm{mmol}$ ), diisopropylcarbodiimide (DIC) and 1-hydroxybenzotriazole (HOBt) in DMF. Compound 7 $(0.48 \mathrm{mmol}, 177 \mathrm{mg})$ was coupled to the last amino acid by a similar strategy. The peptide labelled with the pyrenylindole was cleaved from the resin with a mixture of acetic acid/2,2,2-trifluoroethanol/DCM (2:2:6), giving compound $\mathbf{8}$ as a yellow solid $(50.0 \mathrm{mg}$, $48.5 \%$ ); m.p. $174.0-175.0{ }^{\circ} \mathrm{C} .{ }^{1} \mathrm{H}$ NMR (400 MHz, DMSO): $\delta=$ 1.08 (d, $J=7.2 \mathrm{~Hz}, 3 \mathrm{H}, \mathrm{CH}_{3}$ Ala), 1.09 (d, $J=7.2 \mathrm{~Hz}, 3 \mathrm{H}, \mathrm{CH}_{3}$ Ala), 3.75-3.66 (m, $4 \mathrm{H}, 2 \times \mathrm{CH}_{2}$ Gly), 4.18-4.22 (m, $1 \mathrm{H}, \mathrm{CH}$
Ala), 4.27-4.32 (m, 1 H, CH Ala), 6.97-7.04 (m, 1 H, ArH), 7.30 (t $J=6.8 \mathrm{~Hz}, 1 \mathrm{H}, \mathrm{ArH}), 7.60$ (d, $J=8.0 \mathrm{~Hz}, 1 \mathrm{H}, \mathrm{ArH}), 7.80$ (d, $J=9.2 \mathrm{~Hz}, 1 \mathrm{H}, \mathrm{ArH}), 8.04-8.12(\mathrm{~m}, 7 \mathrm{H}, \mathrm{ArH}+\mathrm{NH}), 8.22-8.42$ $(\mathrm{m}, 6 \mathrm{H}, \mathrm{ArH}+\mathrm{NH}), 12.01(\mathrm{~s}, 1 \mathrm{H}, \mathrm{NH}) \mathrm{ppm} .{ }^{13} \mathrm{C} \mathrm{NMR}$ (400 MHz, DMSO): $\delta=18.26\left(\mathrm{CH}_{3}\right), 18.43\left(\mathrm{CH}_{3}\right), 40.51\left(\mathrm{CH}_{2}\right)$, $41.58\left(\mathrm{CH}_{2}\right), 48.02(\mathrm{CH}), 48.26(\mathrm{CH}), 112.52(\mathrm{CH}), 115.97(\mathrm{C})$, $116.53(\mathrm{C}), 120.19(\mathrm{CH}), 120.33(\mathrm{CH}), 124.01(\mathrm{C}), 124.20(\mathrm{CH})$, $124.33(\mathrm{C}), 125.08(\mathrm{CH}), 125.12(\mathrm{CH}), 125.33(\mathrm{CH}), 126.34(\mathrm{CH})$, $127.37(\mathrm{CH}), 127.47(\mathrm{CH}), 127.51(\mathrm{CH}), 128.33(\mathrm{C}), 128.47(\mathrm{C})$, $129.26(\mathrm{CH}), 129.33(\mathrm{CH}), 129.41(\mathrm{C}), 130.40(\mathrm{C}), 130.48(\mathrm{C})$, 130.88 (C), 135.58 (C), $171.00(\mathrm{C}=\mathrm{O}), 171.62(\mathrm{C}=\mathrm{O}), 171.69$ $(\mathrm{C}=\mathrm{O}), 172.36(\mathrm{C}=\mathrm{O}), 172.39(\mathrm{C}=\mathrm{O}) \mathrm{ppm}$. HRMS (micrOTOF): calcd. for $\mathrm{C}_{35} \mathrm{H}_{32} \mathrm{~N}_{5} \mathrm{O}_{6} 618.23526[\mathrm{M}+\mathrm{H}]^{+}$; found 618.23471 .

Supporting Information (see also the footnote on the first page of this article): NMR spectra of compounds $\mathbf{5}$ and $\mathbf{6}$.

\section{Acknowledgments}

We thank the Portuguese Foundation for Science and Technology (FCT) and Fundo Europeu de Desenvolvimento Regional (FEDER) for financial support to the Centro de Física (CFUM) and Centro de Química (CQ-UM) and through Project PTDC/ QUI/81238/2006. The Bruker Avance II 400 NMR spectrometer is part of the National NMR Network and was acquired with funds from the FCT and FEDER. A. S. A. acknowledges the FCT for a post-doc grant (SFRH/BPD/24548/2005) and G. P. acknowledges the FCT for a PhD grant (SFRH/BD/38766/2007).

[1] a) C. A. Parker, C. G. Hatchard, J. Chem. Soc. Faraday Trans. 1963, 59, 284-295; b) A. C. Benniston, A. Harriman, D. J. Lawrie, S. A. Rostron, Eur. J. Org. Chem. 2004, 2272-2276.

[2] a) S. Egusa, M. Sisido, Y. Imanishi, Macromolecules 1985, 18, 882-889; b) A. Szymańska, W. Wiczk, L. Lankiewicz, Amino Acids 2001, 21, 265-270; c) I. Alves, S. Cowell, Y. S. Lee, X. Tang, P. Davis, F. Porreca, V. J. Hruby, Biochem. Biophys. Res. Commun. 2004, 318, 335-340.

[3] a) P. Demerseman, J. Einhorn, J.-F. Gourvest, R. J. Royer, $J$. Heterocycl. Chem. 1985, 22, 39-43; b) R. Pratap, Y. Tominaga, M. L. Lee, R. N. Castle, J. Heterocycl. Chem. 1981, 18, 973975; c) W. M. Whaley, M. Meadow, C. M. Robinson, J. Org. Chem. 1954, 19, 973-977; d) S. Selvi, S.-C. Pu, Y.-M. Cheng, J.-M. Fang, P.-T. Chou, J. Org. Chem. 2004, 69, 6674-6678.

[4] C.-I. Lin, S. Selvi, J.-M. Fang, P.-T. Chou, C.-H. Lai, Y.-M. Cheng, J. Org. Chem. 2007, 72, 3537-3542.

[5] S.-H. Lu, S. Selvi, J.-M. Fang, J. Org. Chem. 2007, 72, $117-$ 122.

[6] A. S. Abreu, E. M. S. Castanheira, P. M. T. Ferreira, L. S. Monteiro, G. Pereira, M.-J. R. P. Queiroz, Eur. J. Org. Chem. 2008, 5697-5703.

[7] a) A. S. Abreu, N. O. Silva, P. M. T. Ferreira, M.-J. R. P. Queiroz, M. Venanzi, Eur. J. Org. Chem. 2003, 4792-4796; b) M.J. R. P. Queiroz, E. M. S. Castanheira, M. S. D. Carvalho, A. S. Abreu, P. M. T. Ferreira, H. Karadeniz, A. Erdem, Tetrahedron 2008, 64, 382-391; c) M.-J. R. P. Queiroz, A. S. Abreu, M. S. D. Carvalho, P. M. T. Ferreira, N. Nazareth, M. S.-J. Nascimento, Bioorg. Med. Chem. 2008, 16, 5584-5589.

[8] A. S. Abreu, P. M. T. Ferreira, M.-J. R. P. Queiroz, I. C. F. R. Ferreira, R. C. Calhelha, L. M. Estevinho, Eur. J. Org. Chem. 2005, 2951-2957.

[9] D. Creed, Photochem. Photobiol. 1984, 39, 537-562.

[10] B. Albinsson, M. Kubista, B. Nordén, E. W. Thulstrup, J. Phys. Chem. 1989, 93, 6646-6654.

[11] H. Lippert, H.-H. Ritze, I. V. Hertel, W. Radloff, Chem. Phys. Lett. 2004, 398, 526-531.

[12] I. Tatischeff, R. Klein, Photochem. Photobiol. 1975, 22, 221229. 
[13] N. J. Turro, Modern Molecular Photochemistry, Benjamin/ Cummings Pub., Menlo Park (California), 1978.

[14] A. Wiessner, G. Hüttmann, W. Kühnle, H. Staerk, J. Phys. Chem. 1995, 99, 14923-14930.

[15] S. Techert, S. Schmatz, A. Wiessner, H. Staerk, J. Phys. Chem. A 2000, 104, 5700-5710.

[16] W. Wiegel, W. Rettig, M. Dekhtyar, C. Modrakowski, M. Beinhoff, A. D. Schlüter, J. Phys. Chem. A 2003, 107, 5941-5947.

[17] N. Helsen, L. Viaene, M. Van der Auweraer, F. C. De Schryver, J. Phys. Chem. 1994, 98, 1532-1543.

[18] a) W. R. Dawson, M. W. Windsor, J. Phys. Chem. 1968, 72, 3251-3260; b) W. H. Melhuish, J. Phys. Chem. 1961, 65, 229235.

[19] J. V. Morris, M. A. Mahaney, J. R. Huber, J. Phys. Chem. 1976, 80, 969-974.

[20] J. R. Lakowicz, Principles of Fluorescence Spectroscopy, Kluwer Academic/Plenum Press, New York, 1999.

[21] N. Mataga, T. Kubota, Molecular Interactions and Electronic Spectra, Marcel Dekker, New York, 1970.

[22] a) K. C. James, P. R. Noyce, Spectrochim. Acta Part A 1971, 27, 691-696; b) G. R. Wiley, S. I. Miller, J. Am. Chem. Soc. 1972, 94, 3287-3293.

[23] D. R. Lide (Ed.), Handbook of Chemistry and Physics, 83th ed., CRC Press, Boca Raton, 2002.

[24] M. W. Schmidt, K. K. Baldridge, J. A. Boatz, S. T. Elbert, M. S. Gordon, J. H. Jensen, S. Koseki, N. Matsunaga, K. A. Nguyen, S. Su, T. L. Windus, M. Dupuis, J. A. Montgomery, J. Comput. Chem. 1993, 14, 1347-1363.
[25] F. Jensen, Introduction to Computational Chemistry, John Wiley \& Sons, West Sussex, England, 1999.

[26] M. Dekhtyar, W. Rettig, W. Weigel, Chem. Phys. 2008, 344, 237-250.

[27] Z. R. Grabowski, K. Rotkiewicz, W. Rettig, Chem. Rev. 2003, 103, 3899-4031.

[28] G. Jones II, V. I. Vullev, Org. Lett. 2001, 3, 2457-2460.

[29] B. R. Lentz, Chem. Phys. Lipids 1989, 50, 171-190.

[30] J. S. Vincent, S. D. Revak, C. D. Cochrane, I. W. Levin, Biochemistry 1993, 32, 8228-8238.

[31] J. R. Silvius, Lipid-Protein Interactions, John Wiley \& Sons, New York, USA, 1982.

[32] G. E. S. Toombes, A. C. Finnefrock, M. W. Tate, S. M. Gruner, Biophys. J. 2002, 82, 2504-2510.

[33] D. Papahadjopoulos, N. Miller, Biochim. Biophys. Acta 1967, 135, 624-638.

[34] J. M. Seddon, Biochim. Biophys. Acta 1990, 1031, 1-69.

[35] B. Valeur, Molecular Fluorescence - Principles and Applications, Wiley-VCH, Weinheim, 2002

[36] J. N. Demas, G. A. Crosby, J. Phys. Chem. 1971, 75, 991-1024.

[37] S. Fery-Forgues, D. Lavabre, J. Chem. Educ. 1999, 76, 12601264.

[38] A. S. Abreu, P. M. T. Ferreira, L. S. Monteiro, M. J. R. P. Queiroz, I. C. F. R. Ferreira, R. C. Calhelha, L. M. Estevinho, Tetrahedron 2004, 60, 11821-11828.

Received: April 1, 2009

Published Online: June 29, 2009 